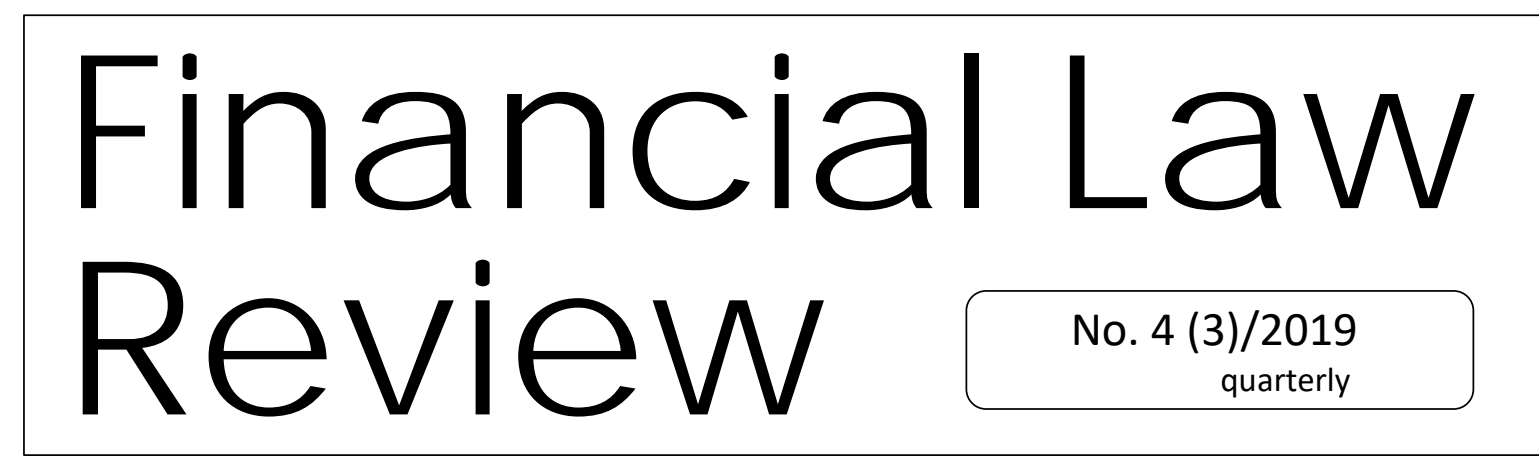

UNIVERSITY OF GDAŃSK • MASARYK UNIVERSITY • PAVEL JOZEF ŠAFÁRIK UNIVERSITY • UNIVERSITY OF VORONEZH http://www.ejoumals.eu/FLR

\title{
THE PRINCIPLE OF THE PRESUMPTION OF INTEGRITY OF THE ENTREPRENEUR PURSUANT TO TAX LAW WOJCIECH PRUS *
}

\begin{abstract}
This article presents an outline of the genesis of the introduction to the Polish legal system of the principle of the presumption of integrity of the entrepreneur. The article proposes several practical guidelines for the application of the principle of the presumption of integrity of the entrepreneur. Certain examples of specific provisions which exclude or question the above principle are also indicated. What is more, the article discusses the subjective scope, as well as several de lege ferenda applications related to the aforementioned principle.
\end{abstract}

Key words: burden of proof, presumption of the integrity of the entrepreneur, principle of freedom of economic activity

JEL Classification: K340

\footnotetext{
* PHD in law Wojciech Bożek, Department of Financial Law, Faculty of Law and Administration, Stettin University, Poland. Author specializes in financial law and local government finance. Contact email: wojciech.bozek@usz.edu.pl, https://orcid.org/0000-0002-3939-3759.
} 


\section{Introduction}

Entrepreneurs are a social group to which the Constitution of the Republic of Poland indirectly refers to Articles 20 and 21 of the Constitution of the Republic of Poland provide, inter alia, the principle of the freedom of economic activity and protection of property. Furthermore, the Constitution clearly states that the social system of Poland consists of the social market economy. The special role of entrepreneurs was emphasized in the preamble to the Act: the law of entrepreneurs, in which constitutional laws concerning entrepreneurs were somehow developed. The preamble contains a postulate of following the principles of legality, legal certainty, non-discrimination and sustainable development towards entrepreneurs.

The principle of the presumption of integrity of the entrepreneur formally applies in Poland with the introduction of the Act of 6 March 2018 - the law of entrepreneurs. The following article shall present an attempt to discover what results from the public authority-entrepreneur relationship (or other persons) and what problems may be put into practice by the application of this principle.

\section{The genesis of the principle of the presumption of integrity of the entrepreneur}

The purpose of introducing the provision in the law stating the principle of the presumption of integrity of the entrepreneur does not seem to be clear. It is true that in the justification for the law the following can be read: "The principle requires the public authorities to assume that, unless the opposition is exhibited (proven), an entrepreneur acts in accordance with the law, honestly and in respect towards good practices. In the light of this principle, for an organ of public authority, an entrepreneur cannot be a suspected entity from the very premise, a person who is alleged to be acting unlawfully, dishonestly or unethically. The public authority must in good faith assume that the entrepreneur respects the law, respects ethics and public morals, as well as acts honestly in his/her relations with other entrepreneurs, consumers and authorities. Each and every deviation from this rule constitute an exception that requires a convincing proof. The aforementioned approach of public authorities ensures building relations between the administration and entrepreneurs on the basis of trust and partnership, supporting the development of entrepreneurship." Nevertheless, it is also recalled that explicit articulation of this principle in the law is the effect of developing or deriving it from the existing constitutional principle - the principle of freedom business [Justification of the draft law of entrepreneurs]. The provision of Art. 10 paragraph 1 of the law, which refers to the principle of the presumption of integrity, requires public authorities to assume that an entrepreneur "acts in accordance with the law, 
honesty and with respect for good practices". The interpretation of this provision may lead to a conclusion that the legislator distinguishes conceptual ranges: actions in accordance with the law, in a fair manner and with respect for good practices.

At the stage of issuing opinions on the draft law - the law of entrepreneurs - one could come across a view that the principle of presumption of integrity of the entrepreneur in some way refers to the presumption of innocence in force under criminal law and the principle of presumption of good faith existing under civil law [Bukowski 2018: 2]. The introduction of this principle also allows to formulate a question - was it possible to presume that an entrepreneur is unfair before the introduction thereof?

\section{The substantial scope of the principle of the presumption of integrity of the entrepreneur}

The literal interpretation of Art. 10 (1) of the law could indicate that the principle of the presumption of integrity of the entrepreneur may apply only to an entrepreneur, as defined in the provisions of the law. The definition of entrepreneur contained in Art. 4 of the law indicates that entrepreneurs are natural persons, legal persons, personal commercial companies conducting business, as well as partners in civil partnerships (also in the judgement of the Provincial Administrative Court in Gdańsk I SA/Gd 1070/18). Such narrowing of the above principle to these categories, however, seems to be erroneous. First of all, due to the fact that other regulations equate the status of entrepreneurs with other people. For instance, pursuant to Art. $5 \mathrm{~b}$ (2) of the law, it is assumed that the income of a partner in a partnership is income from business operations. On the other hand, another law - the Act of 13 October 1998 on the social insurance system for persons conducting business activity - includes not only partners of partnerships but also, for instance, the sole partner of a limited liability company, as well as creators and artists (Art. 8 paragraph 6 point 1-5 of this Act). Second of all, it seems that the principle of the presumption of integrity shall be extended to those who actually represent entrepreneurs, i.e. the members of management boards. This is due to the fact that some legal regulations in some way "equate" the concept of entrepreneur with the representative thereof. For instance, Art. 199 of the Tax Ordinance, referring to premises related to the hearing of a party, is interpreted in such a way that if a legal person is a party to the proceedings, the rigours of the hearing of the party apply to the statutory representative of the legal person [Babiarz, 2019: 2]. Third of all, the above-mentioned broader understanding of the entrepreneur has its justification in the common social understanding of the term "entrepreneur". It shall also be noted that the narrowing of the principle of the presumption of integrity of the entrepreneur to entrepreneurs in the narrow sense conferred by the law of entrepreneurs could be a violation of the constitutional principle of equality before the law. The simplest 
and most vivid example would be a situation in which the situation of partners (natural persons) of a civil partnership on one hand, and partners (natural persons) of a registered partnership on the other. The assumption that the principle of the presumption of integrity would only apply to partners in a civil partnership seems absurd, even in the context of the aforementioned principle of equality.

It shall also be emphasized that it would be difficult to assume a contrario that in the case of persons other than entrepreneurs, public authorities could assume that in relation to such persons it can be presumed that they are not honest. Such reasoning would also be contrary to several constitutional principles, in particular the principle of equality before the law.

\section{The determination of the principle of the presumption of integrity on the basis of tax procedures}

There is no doubt that the application of the principle of integrity of the entrepreneur shall in particular occur on procedural grounds - along the axis: tax authority (or other public authority) - taxpayer, to the extent that would not cause any unreasonable, excessive difficulties in performing certain duties. It seems that several practical tips resulting from this principle can be distinguished.

\section{a) Official dates and deadlines}

In the course of tax proceedings (as well as, respectively, during tax or customs audit), various types of deadlines are set for performing certain activities, e.g. the submission of explanations. It occurs that if a person called presents arguments (without enclosing evidence) about the impossibility of making the summons within a specified time limit, the public authority should, in principle, assume that such person acts in an honest manner. The effect of this shall be to allow the requested explanations, documents, etc. at a later date. In other words, in situations where no provision of the Act requires a proof or even a substantiation of certain circumstances invoked, public authorities, including in particular tax authorities, shall assume that an entrepreneur applying for an extension of the official period operates honestly, having in fact valid reasons and justifications. Regarding the issue of official deadlines in the context of the principle of the presumption of integrity of the entrepreneur, the following example may be used. Example: Let us assume that a tax procedure is pending with respect to a given entrepreneur, concerning a quite distant period (e.g. from 4 years ago) and related to a fairly broad scope of the subject (e.g., checking all settlements due to tax liability in the income tax of legal persons). In the course of such proceedings, a request is made to provide: any protocols for accepting works, employee cards, etc., such a call is delivered personally - in the domicile of the 
entrepreneur on Friday, with a deadline of 3 days. The deadline of 3 days will be in this case on Monday, which means that the given entrepreneur can realistically have only a few hours to prepare the requested documentation. The delivery of the call - with such a short real deadline for execution, in essence, violates the principle of integrity of the entrepreneur, as it implies that the public authority assumes that for a longer time to perform the call, the entrepreneur may make some changes to the documentation. It is difficult to look for any other rational reasons for such a short period of time. The implementation of the principle of the presumption of integrity of the entrepreneur shall, inter alia, manifest itself in such situations in trust in entrepreneurs.

\section{b) The principle of the presumption of integrity and the burden of proof}

The issue of the so-called the burden of proof in tax proceedings has undergone some evolution. While the provisions of the Tax Ordinance did not contain the civil law rule on the burden of proof, contained in Art. 6 of the Civil Code, initially the jurisprudence accepted the view that the burden of proving a fact lies with the entity that derives legal consequences from a given fact (compare the judgement of the Supreme Administrative Court in Warsaw III SA $1874 / 99$ or the judgement of the Provincional Administrative Court in Poznan I SA/PO 2079/98). Simultaneously, it shall be emphasized that the second line of jurisprudence was developing at the same time, which assumed that the burden of proof is in principle on the tax authority (compare the judgement of the Provincional Administrative Court in Gdańsk I SA/Bg 4/97).

In later decisions, it was usually assumed that the burden of proof rests, as a rule, on the tax authority, unless the initiative of a taxpayer himself/herself or a special tax act transfers it in a way to the taxpayer [Borszowski 2019: 2]. An interesting issue may be the question whether the principle of the presumption of integrity of the entrepreneur is modified by the distribution of the burden of proof in tax proceedings. It seems that in the circumstances where the provision of the Tax Act clearly does not indicate the obligation to prove certain facts (an example may be Art. 116 of the Tax Ordinance, in which the use of exculpatory conditions is clearly dependent on the "indication" of a member of the board of certain facts), the same substantiating of certain circumstances by a taxpayer shall be sufficient as an expression of the actual implementation of the principle of the presumption of the integrity of the entrepreneur-taxpayer.

\section{c) Explanations or evidence from the hearing of a party?}

During the tax proceedings, explanations may be received from a taxpayer. The same circumstances can be determined by the tax authority, not on the basis of explanations but as part of the evidence from the questioning of the party (the Tax Ordinance, Art. 155). The view prevails in the literature that in the tax proceedings, the explanations of a party 
do not have the value of evidence [Strzelec 2015: 2-5], while the evidence is without doubt the evidence from the questioning of the party. It shall be noted that the evidence from the questioning of a party is carried out under a certain pressure, due to possible criminal liability of the party for the testimony of untruth or the concealment of truth. In the light of the aforementioned two possibilities of obtaining information from the proceedings (taxpayer), there is a doubt whether the introduction of the principle of the presumption of integrity of the entrepreneur may have some significance in choosing one of the two forms over the other. It appears that if an element of the principle of the presumption of integrity of the entrepreneur is certain trust, which shall be granted by the public authorities in advance, evidence from the questioning of a party in the tax proceedings shall not be abused. It is worth noting that the provision of Art. 199 of the Tax Ordinance regulating the question of the interrogation of a party, in the original wording thereof, contained a reservation that it could be applied "after exhausting other means of proof or because of lack thereof" (the Tax Ordinance, Art. 199 in the original wording). Thus, the proof was treated as the final or last in the hierarchy of evidence in the original version [Małecki 2015: 405]. In the civil procedure, the equivalent of Art. 199 of the Tax Ordinance is Art. 299 of the Code of Civil Procedure, the hypothesis of which is almost identical to the hypothesis of the former Tax Ordinance. Although the regulation of civil procedure is difficult to compare directly to the regulation of tax procedures, it is noted in the literature on the questioning of a party in the civil procedure that the credibility of the evidence from the questioning of the party shall not be assumed in advance [Jakubecki 2018: 1). It seems that on the basis of tax law, one may go a step further. Obviously, it shall also not be assumed a priori that due to subjectivity, the testimony of a party will be of little use. The introduction of the principle of the presumption of integrity of the entrepreneur shall mean that, where applicable, the tax authorities should stop at receiving only the explanations of a party, and the evidence from the interrogation should be carried out less frequently.

The right to request explanations from a party during tax proceedings results directly from Art. 155 of the Tax Ordinance. It shall be noted that already after the introduction of the law: the law of entrepreneurs, in addition to the legal order, the Act of 9 November 2018 on amending certain acts was introduced in order to introduce simplifications for entrepreneurs in tax and economic law which was introduced into the Tax Ordinance with Art. $155 \$ 1 \mathrm{a}$ which elaborates on the so-called the inconvenience of calls. If the calls themselves (implicitly - inter alia provide explanations - see Art. 155 of the Tax Ordinance) are to be unobtrusive, according to the rule a minori ad maius, it can be assumed that the more should not be burdensome - that is, the acts of evidence are abused, consisting in the questioning of a party. Questioning of a party is a mean of proof that can only be used if the party agrees thereto. It results directly from Art. 199 of the Tax Ordinance. The jurisprudence states that a request for explanations in some situations may 
lead to circumvention of Art. 199 of the Tax Ordinance (compare the judgement of the Provincional Administrative Court in Wrocław I SA/Wr 549/18). Therefore, the request for explanations is limited not only by the presumption of integrity of an entrepreneur/taxpayer, but also by the principle of non-inconvenience (which seems to be however, developing the principle of the presumption of integrity), as well as the obligation to obtain the consent of a party. It is worth to note that the specialists have been postulating more friendly solutions in relations between the taxpayer and tax authorities [Filipczyk 2016: 3-4].

\section{Presuming the integrity of an entrepreneur in the context of his/her previous behaviour}

When applying the principle of the presumption of the integrity of the entrepreneur, there may be a doubt as to how the entrepreneur's previous behaviour influences or should affect the perception thereof by the public authorities. In the very beginning, it shall be noted that Art. 10 of the law of entrepreneurs contains two principles: the principle of the presumption of integrity of the entrepreneur (section 1) and the principle of resolving doubts as to the facts in favour of the entrepreneur (section 2). In relation to the latter principle, however, reservations have been added (para. 3) - negative aspects of use, including, inter alia, special regulations (para. 3 point 2). It seems, however, that some of the specific regulations may also exclude or weaken the principle of the presumption of integrity of the entrepreneur. For instance, Art. 96 (4a) (5) of the Value Added Tax Act states that at the registration of a taxpayer for the purposes of value added tax (or delete a registered taxpayer) may be refused if the information available indicates that the taxpayer may conduct activities with the intention of using activities of banks within the meaning of Art. 119 clause 1 of the Tax Ordinance or Cooperative Savings and Credit Unions for purposes related to tax fraud within the meaning of Art. 119 according to point 9 of the Tax Ordinance. Therefore, this provision does not even refer to "possession of evidence" but "possession of information", as a premise that allows issuing a registration decision for the purposes of the tax on goods and services. This type of regulation may be treated as a special provision in relation to Art. 10 paragraph 1 of the Act. In the literature, it is noted that "possession of information" within the meaning of the aforementioned Art. 96 (4a) (5) of the Act on Value Added Tax is most often the result of appropriate calculations of secret algorithms created by the Ministry of Finance [Krywan 2017: 3]. It denotes that not entirely clear algorithms decide whether the presumption of integrity is to be refuted in relation to a given entrepreneur. The aforementioned example raises doubts as to compliance with the Constitution of the Republic of Poland, for instance in the context of the democratic state of law, due to the fact that there are no clear statutory criteria to exclude the principle of the presumption of integrity of the entrepreneur. It should be noted that tax authorities are 
classifying the taxpayers before the registration for VAT purposes and also are using special tables (for example so called Table-T11 ${ }^{1}$ ) for describing the "level of risk" linked with the taxpayer (NIK, 3-7). Other examples of special provisions are the regulations contained in Art. 86a-86o added to the Tax Ordinance added from 1 January 2019, ordering reporting on the so-called tax schemes. These provisions in fact presuppose that in certain cases - for instance, by the mere fact of undertaking by an entrepreneur to keep confidential information on the manner of application of tax law provisions (vide: Art. 86a $\$ 1$ point 6 a) of the Tax Code), which he obtained from a professional lawyer, is an undesirable action, obliging him/her to inform the competent authorities. Apart from the specific provisions, it seems that an entrepreneur's negative past behaviour should not exclude the application of the principle of the presumption of integrity of the entrepreneur in a given case.

\section{Presumption of the integrity of the entrepreneur - assumption of acting in accordance with the law, honest and respecting good practices}

Art. 10 (1) of the law uses the wording "acting in accordance with the law, honest and respecting good practices." Since this provision distinguishes these three concepts, it should be assumed that the application of the principle of the presumption of integrity of the entrepreneur has a much broader scope than the presumption of innocence applicable in penal law. While the presumptions of "acting in accordance with the law" and "respecting good practices" shall not raise any doubts, the same presumption of acting in an honest manner may pose a lot of doubt as to the content of this part of the provision. First of all, such a distinction of concepts raises the question of whether illegal action is possible but fair, or lawful but unfair. In particular, a question may also arise as to whether the content of the provision is a "disservice" introduced with respect to entrepreneurs. The literal interpretation of this provision may lead to the conclusion that the role of public authorities is not only to test compliance with the law, but also to test the integrity of an entrepreneur. The very word "honest" is not defined, of course, under the Act: the law of

\footnotetext{
${ }^{1}$ The Table-t11 is an array containing a list of „specific entities” („Baza podmiotów szczególnych”), introduced by non-statutory [Decision of Ministry of Finance nr 54] in which there are entities (taxpayers) who are under special supervision-see:

http://bydgoszcz-ap-arch.mf.gov.pl/c/document_library/get_file?uuid=4220b776-651c-455f-ade15046f1d86884\&groupId=3319704,

the taxpayers who are listed in the table t11 could have problems with registration for tax purposes and with more intense supervision; the part of the Table-t11 includes also the list of unreliable entities -see also: http://www.wielkopolskie.kas.gov.pl/documents/3470530/5325464/20180209 wystapienie pokontrolne us oborniki.pdf, p5:

there are non-statutory internal regulations which are containing unclear and secret criteria according to which taxpayers are placed on the list of unreliable taxpayers, and there is no official procedure for applying to be removed from such a list.
} 
entrepreneurs. According to the dictionary definition, "honest" is: "Honest in the proceedings, respecting someone else's property, unable to deceive; also: having such features», «in accordance with accepted rules or law» or «consistent with reality or truth» (PWN 2016: 134). Essentially, the main definitions of the word "honest" go beyond the scope of legitimate activity. In order to make the aforementioned considerations practical, the following example shall be used. Entrepreneur A is running a business in a rented place of a natural person B. Let us assume that the entrepreneur has lost documents related to renting the premises, and the natural person $\mathrm{B}$ has gone abroad for a time and is unreachable. In the case of tax audit, the entrepreneur is not able to present documents related to the lease of the premises, which exposes him/her to adding the so-called value to revenues, the so-called free benefits. In this situation, the presumption of integrity - in this narrower sense - shall lead to the assumption that: the entrepreneur acts in accordance with "respect for other people's property" (vide: the aforementioned dictionary definition) as a result, he/she reliably settles for rent. The effect of applying the principle of the presumption of integrity should in such a situation be to enable the entrepreneur $\mathrm{A}$ documents to be restored within a reasonable period (see comments in item 3 a)). Another interesting example may be circumstances related to avoiding the contact of an entrepreneur with a public authority and the assessment of such activities in the context of good or bad faith of a taxpayer. As an example, cases related to the refund of tax on goods and services can be provided. The tax authorities have a strictly defined deadline to refund the tax on goods and services - it is usually 60 or 25 days from the submission of a tax return in which the refund amount is shown. The extension of this deadline is possible only if a decision on the extension of the tax refund deadline is delivered before the expiration of such time limit (compare the Judgement of the Supreme Administrative Court, I FSK 255/17). In this judgement the provisions of substantive and procedural law, as well as a categorical statement that the decisive for extending the term of refund of tax on goods and services is not issuing and delivery of the relevant provision is decisive, can be found.

Especially in cases where the tax authority is bound by a 25-day period for the refund of tax on goods and services, it may in practice come to a situation of avoiding the contact of an entrepreneur with the tax authority. In one of the recent judgements (Judgement of the Supreme Administrative Court FSK 1701/16) regarding the same subject matter - delivery of a decision on extending the deadline for refund of tax on goods and services, it was stated that: "The actions and omissions of the parties to the proceedings aimed at deliberate refusal to receive correspondence addressed to them constitute an example of the abuse of procedural rights and do not deserve protection in a democratic state of law." It shall be noted that the approach presented in the second ruling raises the problem of assessing whether the actions of a taxpayer are deliberate or not. Considering the fact that the assessment of such bad faith of a taxpayer must be made extremely fast (due to the short deadlines for the refund of goods and services), it is hard to imagine that it would 
always be possible to collect evidence confirming bad faith in such a short period. In such situations, there will often be a conflict between respecting the principle of the presumption of integrity of the entrepreneur and briefly collected evidence assessing the possible bad faith of a taxpayer/an entrepreneur.

\section{Trust to entrepreneur}

Trust is phenomenon which over the past decades has gained attention across many fields and disciplines of social sciences. The economic studies show that trust reduces the cost of transactions (less time is spend investigating one's broker) and that high trust societies exhibit better economic performance than low trust societies as shown in the empirics [Knack and Keefer 1997]. Taking into account such studies one could risk the claim that trust reduces the cost of collection of taxes from one hand and save time of entrepreneurs from the other hand.

The principle of the presumption of integrity of the entrepreneur also stipulates that tax authorities are guided in its actions by the principle of trust in the entrepreneur. What the term "trust" should mean? Trust is only meaningful if understood bilaterally [Mitchell 1999: 39-40]. The literature identifies several factors that contribute to the development of trust [Whincop 2001: 5]. In the relation between taxpayer and tax authority it breaks down the adversarial quality of bilateral relations and encourages cooperation. Trust also seems to be closely related to the procedural content of the relation [Thibaut, Walker 1975: 390]. So it should be noted, that one of the main principle in tax ordinance is the principle of deepening trust in tax authorities. So there are two principles concerning trust, both are addressed to tax authorities -and are obligating them to building bilateral relation based on trust. So it seems, that the new principle complements the legal system about the queries related to building trust. It would be interesting what it should mean in practise. There is a lot judgements what this second principle should mean. In the judgment of the Provincial Administrative Court in Kielce I SA / Ke 414/18, states that "The principle of conducting proceedings in a way that inspires confidence in tax authorities (Article 121 of the Act) means, inter alia, that proceedings conducted by the body must lead to the application of substantive provisions in conditions of impartiality and taking into account the circumstances favorable to the party. In other judgments, it is argued that breaching the principle of deepening trust in tax authorities is to issue two different tax interpretations without giving reasons sufficiently clearly justifying the seizure of another position (see judgement of the Supreme Administrative Court I FSK 142/17, or the judgement of the Provincial Administrative Court in Gliwice III SA / Gl 165/18). The list of situations in which the principle of deepening trust in tax authorities may be violated is difficult to catalog, but the analysis of the judgements itself indicates that often not only 
the tax authorities referring to the argumentation concerning violation of the principle of deepening trust in tax authorities, as counterarguments circumstances that are contrary to this second principle - i.e. the principle of trust in entrepreneurs. For example, in the judgment of the Supreme Administrative Court I FSK 651/18, it was found that the share capital of the company - PLN 5,000, in comparison to a relatively small amount of tax refund for goods and services (the amount is just over PLN 55,000), calls into question the reliability of the taxpayer and, consequently, the legitimacy of the tax refund. In judgements, the reference to the principle of trust in entrepreneurs in the context of the application of provisions that are difficult or even impossible to apply is very rare. For example, Article 21 (1) of the Bankruptcy Act obliges the debtor entrepreneur to file for bankruptcy within 14 days of the insolvency. The consequences of not submitting the application in time could be painful not only for the entrepreneur, but also for the representatives of such an entrepreneur - no. members of the management board (eg. the possibility of joint and several liability for tax liabilities pursuant to Article 116 of the Tax Ordinance). This provision has been amended, but it is interesting to justify the draft law amending the bankruptcy law, in which it states, quoted: "The current two-week deadline is far too short and so much that in practice there are no applications submitted on time. In a medium-sized enterprise, with extensive accounting services, it is not possible to determine, practically overnight, that there is a state of insolvency defined in art. 11 Bankcrupcy Act." (Governmental Bill - Restructuring Law, Text No. 2824). Although the legislator body himself admitted that the provision of the Act was impossible to apply in practice, on the basis of such a provision, unfavorable decisions for representatives of entrepreneurs were issued all the time (Judgment of the Supreme Administrative Court II FSK 3532/16). By transferring the issues of judgments to the ground of applying the principles of building trust between public authorities and entrepreneurs, it is impossible to escape from the remark made at the outset that trust is a bilateral relationship. If public authorities act in such a way that entrepreneurs will not trust them, the very order to conduct trust in entrepreneurs seems to be just an empty postulate. It is obvious that building such a bilateral relation should be not only an romantic idea, but it should be also treated as something that is creating the effective tax collection, without repressive measures and coercion from one hand and is building a friendly environment for entrepreneurs, which could save their time and could focus on business. It has been shown in the past that legal procedures should take into account two types of costs: „error costs" (the social costs generated when a judicial system fails to carry out the allocative or other social functions assigned to it), and the „direct costs” (such as lawyers, time involved by officials, judges , and litigants' time) of operating the legal dispute-resolution machinery [Posner 1973: 399-400]. Those types of costs should be taken in account also in tax procedures. 


\section{Final Conclusions}

The introduction of the principle of the presumption of integrity of the entrepreneur is undoubtedly a step towards achieving the principle of supporting entrepreneurship, respecting the principle of a democratic state of law and respecting economic freedom. The significance of this principle should not be questioned in these relations which concern, in particular, official deadlines, the distribution of the burden of proof and a certain hierarchy of evidence. Of utmost importance shall be the analysis of this principle in the context of special provisions which, a priori, give the possibility to depart from the application thereof. In such cases, at least some general patterns or rules of an objective nature that would allow for a departure from the application thereof should be developed. De lege ferenda, one can also put forward a postulate to extend this principle to a broader group of entities - to entrepreneurs in a broad sense - in particular to partners of personal commercial companies, representatives of such companies or creators. This principle may be considered as a supplement to the rules known from other legal branches - in particular the presumption of innocence, which occurs on the basis of criminal law and the principles of good faith in civil law. It also seems that it is not possible to make the thesis that the principle of the presumption of integrity of an entrepreneur earlier (i.e. before the formal introduction thereof) did not apply. This principle is derived directly from the Constitution, and it would be difficult to conclude that before the introduction thereof, the assumptions about the integrity of an entrepreneur could not have been made. The principle is in contradiction with the exemplary regulations indicated and also with internal instructions of tax authorities. The application of the principle should not only contribute to the implementation of constitutional values, but it should also be used for pragmatic (economic) reasons, simplifying and shortening tax proceeding.

\section{References:}

Babiarz S., et al. Ordynacja podatkowa [Tax Ordinance], Warszawa: Wolters Kluwer, 2019. Borszowski, P., Ciężar dowodu w postępowaniu podatkowym [The Burden of Proof in Tax Proceedings], Warszawa: Wolters Kluwer, 2009.

Brockner J., Siegel P., Understanding the Interaction Between Procedural and Distributive Justice: The Role of Trust (in:) Kramer, R., Tyler, T. Trust in Organizations: Frontiers of Theory and Research, Sage Publications Inc., 1996.

Jakubecki, A., (ed.), Kodeks postępowania cywilnego. Komentarz aktualizowany. Tom I. Art. 1-729 [Code of Civil Procedure. Updated Commentary. Vol. I. Articles 1-729]. Updated comment. Volume I. Art. 1-729, Published in: LEX/el., 2018.

Knack, Stephen and Keefer, Philippe, Institutions and economic performance: Crosscountry tests using alternative institutional measures, Economics and Politics, No. 7, 1995 
Krywan T., Mikuła P., Przesłanki braku rejestracji i wykreślenia podmiotu jako podatnika VAT - ustawa o STIR [Premises of non-registration and deletion of the entity as a VAT payer - Act on STIR], LEX el., 2017.

Małecki J. (in:) Gomulicz A., Małecki J. Taxes and Tax Law, Warszawa: LexisNexis, 2004

Mitchell, L., Trust and Team Production in Post-Capitalist Society, Journal of Corporation Law, Vol. 24, No. 4, 1999.

Posner R., An Economic Approach to Legal Procedure and Judicial Administration, The Journal of Legal Studies Vol. 2, No. 2, 1973.

Strzelec, D., Dowody i postępowanie dowodowe w prawie podatkowym [Evidence and evidentiary proceedings in tax law], LEX el., 2015.

Thibaut J., Walker L., Procedural Justice: A Psychological Analysis, Lawrence Erlbaum, 1975.

\section{Internet Resources:}

Bukowski, M. Opinia do projektu ustawy prawo przedsiębiorców [Opinion to the Draft Project of the Law of Entrepreneurs], available at: https://orka.sejm.gov.pl.

Decision of Ministry of Finance nr 54 from $30^{\text {th }}$ of May of 2014, available at:

Filipczyk, H., Alternative Methods for Resolving Tax Disputes in Poland.- The Odds of Success, available at: https://papers.ssrn.com/sol3/papers.cfm?abstract id=2759842, 2016.

http://bydgoszcz-ap-arch.mf.gov.pl/c/document library/get file?uuid=4220b776651c-455f-ade1-5046f1d86884\&groupId=3319704.

NIK - Najwyższa Izba Kontroli, Delegatura w Poznaniu, Wystąpienie Pokontrolne nr LPO.410.027.01.2017, available at:

https://www.google.com/url?sa=t\&rct=j\&q=\&esrc=s\&source=web\&cd=11\&ved=2ah UKEwjVrfP1xbfiAhVttIsKHa0JAtcQFjAKegQICBAC\&url=https\%3A\%2F\%2Fwww. nik.gov.pl\%2Fkontrole\%2Fwyniki-kontrolinik\%2Fpobierz\%2Clpo p $17 \quad 013 \quad 201803200934221521538462 \sim$ id0 01\%2Ctyp\%2 Ckj.pdf\&usg=AOvVaw3c7iPWXeBaPCWXkIkXFWss.

Whincop, M.J., Entrepreneurial Governance, available at: https://papers.ssrn.com/sol3/papers.cfm?abstract id=254169, 2001.

Zak P., Trust and Growth, Available at: https://papers.ssrn.com/sol3/papers.cfm?abstract id=136961, 1998.

\section{Legal Acts:}

Constitution of the Republic of Poland (Journal of Laws 1997, No. 78, item 483 as amended).

Act of $17^{\text {th }}$ November 1964 - Code of Civil Procedure (consolidated text Journal of Laws 2019, item 1460).

Act of $26^{\text {th }}$ July 1991 on personal income tax (consolidated text Jounral of Laws 2019, item 1387).

Act of $6^{\text {th }}$ June 1997 - Criminal Procedure Code (consolidated text Journal of Laws 2018, item 1987). 
Act of $29^{\text {th }}$ August 1997 - Tax Ordinance (consolidated text Journal of Laws 2019, item 900).

Act of $13^{\text {th }}$ October 1998 on the social insurance system (consolidated test Journal of Laws 2019, item 300 as amended).

Act of $28^{\text {th }}$ February 2003 - Bankruptcy Law (version valid until December $31^{\text {st }}, 2015$, Journal of Laws 2015, item 233 as amended).

Act of $11^{\text {th }}$ March 2004 on tax on goods and services (consolidated text Journal of Laws 2018 , item 2174 as amended).

Act of $6^{\text {th }}$ March 2018 - Law of Entrepreneurs (consolidated text Journal of Laws 2019, item 1292).

Act of $9^{\text {th }}$ November 2018 on amending certain acts was introduced in order to introduce simplifications for entrepreneurs in tax and economic law (Journal of Laws 2018, item 2244).

\section{Court Rulings:}

Judgement of the Supreme Administrative Court in Warsaw on $19^{\text {th }}$ December 2000, III SA $1874 / 99$.

Judgement of the Provincial Administrative Court in Gdańsk on $29^{\text {th }}$ January 2019, I SA/Gd 1070/18.

Judgement of the Provincional Administrative Court in Poznan on $20^{\text {th }}$ January 2000, I SA/PO 2079/98.

Judgement of the Provincional Administrative Court in Gdańsk, I SA/Bg 4/97.

Judgement of the Provincional Administrative Court in Wrocław on $8^{\text {th }}$ August 2018, I SA/Wr 549/18.

Judgement of the Supreme Administrative Court, on $20^{\text {th }}$ November 2017, I FSK 255/17.

Judgement of the Supreme Administrative Court, on $10^{\text {th }}$ October 2018, I FSK 1701/16.

Judgment of the Provincial Administrative Court in Kielce on February $28^{\text {th }}$ 2019, I SA / Ke $414 / 18$.

Judgement of the Supreme Administrative Court of $7^{\text {th }}$ February 2019, I FSK 142/17.

Judgement of the Provincial Administrative Court in Gliwice on May $21^{\text {st }}, 2018$, III SA / Gl $165 / 18$.

Judgment of the Supreme Administrative Court of $26^{\text {th }}$ June 2018, I FSK 651/18.

Judgment of the Supreme Administrative Court of $11^{\text {th }}$ October 2018, II FSK 3532/16.

\section{List of abbreviations:}

Bankruptcy Act - Bankruptcy Law

CC Procedure - Code of Civil Procedure

CCr Procedure - Criminal Procedure Code

NIK - Supreme Chamber of Control

NSA - Supreme Administrative Court

Tax Ordinance -Tax Ordinance Act

updof - Act on personal income tax

VAT - value added tax ("podatek od towarów i usług" -tax on goods and services) 
WSA - provincial administrative court 